\title{
A COMPARATIVE STUDY OF THE EFFECT OF DIFFERENT TECHNIQUES OF COOPERATIVE LEARNING AND SELF-CONFIDENCE UPON STUDENTS' SPEAKING COMPETENCY
}

\author{
Joni, D. A. A. W \\ Language Education Study Program, Postgraduate Program \\ Ganesha University Of Education \\ Singaraja, Indonesia \\ e-mail: wiryadi.joni@undiksha.ac.id,
}

Nitiasih, P.,K. Language Education Study Program, Postgraduate Program Ganesha University Of Education Singaraja, Indonesia e-mail: titiekjegeg@gmail.com,

Artini, L. P. Language Education Study Program, Postgraduate Program Ganesha University Of Education Singaraja, Indonesia e-mail: 1partiniundiksha@yahoo.co.id.

\begin{abstract}
This study focused on: 1) investigating the significant difference in speaking competency between the students taught by using Jigsaw II and those taught by using STAD; 2) investigating the interactional effect between teaching techniques and self-confidence upon students' speaking competency; 3) investigating the significant difference in speaking competency between the students with high selfconfidence taught by Jigsaw II and those taught by STAD; and 4) investigating the significant difference in speaking competency between the students with low self-confidence taught by Jigsaw II and those taught by STAD. The findings show that, firstly, the students treated by Jigsaw II achieve better speaking competency than those treated by STAD; secondly, there is an interactional effect between teaching techniques and self-confidence on the students' speaking competency; thirdly, the students with high-self-confidence gain higher speaking competency when being treated by Jigsaw II than by STAD; and fourthly, the students with low self-confidence attain the same speaking competency achievement when being treated by Jigsaw II and STAD.
\end{abstract}

Keywords: speaking competency, cooperative learning, Jigsaw II, STAD, self-confidence.

\section{INTRODUCTION}

The typical phenomena happened in EFL speaking class is the teacher's dissatisfaction in students' competency of the assigned speaking tasks. The foreign language (FL) speaking process involves the interplay of two language systems. When speaking in a foreign language, speakers have access to their first language (L1) and often use their L1 as a speaking strategy to translate the targeted language in their brain. But, frequently, it needs time and provokes puzzlement among learners. In short, speaking in nonnative language requires extra efforts and learners find it quite hard to fluently speak in foreign language.

Many potential reasons affect a student on learning to speak in years of schooling. Some of them may be because of students' intrinsic factors, which is students' self-confidence, while others are due to outside influences, which is teaching technique.

Accordingly, rather than implementing activities and exercises which focus strictly on content (such as memorization, repetition, and uncontextualized drills) (Riggenbach and Lazaraton et. al., 1991) which 
neglect training of any skills involving effective interplay between both teacher-student and studentstudent in the EFL classroom as have been fostered in conventional teaching techniques, many classroom teachers are expected to concentrate on promoting communicative competence in language learners by using "communicative activities" (Canale et al., 1991), which focus on the students' ability to understand and communicate real information. For this reason, many experts believe that cooperative learning can encourage these communicative activities in classroom settings.

A careful selection of teaching techniques, then, is required. It must be teaching techniques which are appropriate to teach language and are able to mainly foster language skills as well as to lead students to be confident EFL speakers through working cooperatively. The ones teaching technique that answer and match the aforementioned explication are Jigsaw II and STAD. As been cited in Wang, who did a study of using cooperative learning models to teach conversational skills in 2009. The findings showed that the students had gone through learning motivation to listen and to speak, interpersonal relation, and cooperative work to go on the same goal. STAD and Jigsaw II techniques also endorsed opportunities for interaction and communication among students and improved the speaking and listening strategies such as for gist sequence, main ideas and details.

On the other hand, viewing from students' intrinsic factor, self-confidence plays an important role to influence students' achievement in learning process. Based on Clemet in Molberg (2010), self-confidence is defined in terms of self-perception of second or foreign language competence and a low level of anxiety.

With respect of the essential of speaking competency for EFL students, their self-confidence that they attach with, and the problems faced in communicating Englsih as foreign language, the researcher has accomplished a research about the effect of different techniques of cooperative learning and selfconfidence upon students' speaking competency.

Speaking is more that just being able to speak fluently in English or being able to pronounce phonemes correctly or using appropriate stress and intonation patters as well as speaking in connected speech but speaking is not as simply as aforesaid meaning. Based on Harmer (2007), speakers of English must be able to speak in a variety range of different genres and situations and they must be able to speak in a field of conversational strategies. They will need to be able to see in typical functional exchanges as well. But, one point to remember is that each speaker undergoes different speaking processes as they build their own knowledge and have different prior knowledge.

Opposing the speaking process, the product of speaking is the communication of thoughts and emotions by the speaker towards the interlocutors. The success of communication is related to how competent a speaker consigns a message. When speakers understand the intention of particular oral language then the meaning of sounds is met. It results from the speaker's production of meaning through blending his prior knowledge with the communicative competence. When these speaking acts have lasted, the comprehension is represented in the knowledge then gathered from the speaking experience and reflect it in society (Dorn and Soffos in Al-Hebaish, 2012). This is due to one of the important components of communicative competence, which is an awareness of the differences between formal and informal language used in real life contexts and situations.

The EFL or SL speaker, who is said to be competent if they are able to utilize their prior knowledge and oral skills into account in daily life and benefit towards human race. However, speaking is a priority to any second or foreign language learners though it is very complex. Research has thrown considerable light on the complexity of spoken interaction in either a first or second language. For example, Luoma (2004) cites some of the following features of spoken discourse: composed of idea units (conjoined short phrases and clauses), planned (e.g., a lecture) or unplanned (e.g., a conversation) speech, employs fixed phrases, fillers, and hesitation markers, contains slips and errors reflecting online processing, involves reciprocity (i.e., interactions are jointly constructed), shows variation (e.g., between formal and casual speech), reflecting speaker roles, speaking purpose, and the context.

Competency, however, refers to the ability or skill to do something well. The ability itself may be in any term. Furthermore, competencies, according to Richards and Rodgers (2001), consist of essential skills, knowledge, attitudes, and behaviors required for effective performance of a real-world task or activity. It can be said that competency is not only about capability of doing something but also about the knowledge of considered terms, the way learners act in particular, the way learners think or behave, etc, which is considered to be acceptable in society or real daily life. Thus, competency can direct learners to be an educated or competent part of society. 
In light with this, Docking in Marcellino (2005) strengthens the abovementioned theory. He mentions that a unit of competency can be achieved through a task, a role, a function, or a learning module. These will vary from context to context. Therefore, competency may consist of specific knowledge, thinking processes, attitudes, and both perceptual and physical skills. All of these may be linked to any sphere of life in the field of work and social survival in a new environment. Hence, being competent, having such competencies, means being able to blend in society. It can be gained through doing communication with each other by practicing as well as enhancing communicative skill, which is speaking competency.

Thus, speaking competency means that students must be competent in using spoken language, which includes components of competency such as essential skills, knowledge, attitudes, and behaviors, it is essential to note down major components of speaking as well. based on Luoma (2004), speaking competency is defined as a strategic process involving speakers in using language for the purpose of achieving a certain goal in a particular speaking task, which includes, essential skills, knowledge, attitudes, and behaviors required for effective performance of a real-world task or activity (Richards and Rodgers, 2001). Speaking competency is heavily dependent on intelligibility of pronunciation, an understanding of grammar, fluency, vocabulary and appropriate content.

Cooperative Learning is considered to be an approach to organize activities into academic and social learning experiences. Students must work in groups to complete tasks collectively. Unlike individual learning, students learning cooperatively capitalize on one another's resources and skills (asking one another for information, evaluating one another's ideas, monitoring one another's work, etc.) (Hiçyilmaz, 2005).

To be successful in setting up and having students complete group tasks within a cooperative learning framework, a number of essential components or requirements must be met as follows:

\section{Positive interdependence}

Teachers must arrange learning tasks so that students come to believe that they sink or swim together - that is, their access to rewards is as a member of an academic team wherein all members receive a reward or no member does. Essentially, tasks are structured so that students must depend upon one another for their personal, teammates', and group's success in completing the assigned tasks and mastering the targeted content and skills.

\section{Face-to-face interaction}

Students need to set up themselves so that they are positioned and postured to direct eye-to-eye contact and face-to-face academic conversations.

\section{Positive social interaction behaviors and attitudes}

Simply because students are put in groups and asked to use appropriate social and group skills does not mean students will automatically use these skills. To work together as a group, students need to introduce in such interactive abilities as leadership, trust-building, conflict-management, constructive criticism, encouragement, compromise, negotiation, and clarifying. Teachers may need to describe the expected social interaction behaviors and attitudes of students and to assign particular students specific roles to ensure that they consciously work on these behaviors in their groups.

\section{Individual accountability}

The potential reason why teachers put students in cooperative learning groups is so all students can achieve higher academic success individually than are they to study alone. Therefore, each must be held individually responsible and accountable for doing his or her own share of the work and for learning what has been targeted to be learned. Consequently, each student must be formally and individually assessed to determine the extent to which he or she has mastered and retained the targeted academic content and abilities.

\section{Jigsaw II}

Jigsaw II is the mutation of Jigsaw technique (Slavin, 2009). However, the students here work in four-or five-member teams. The implementation of this technique is structurally described below:

1. Reading. In reading section, all students read a general text, such as a book chapter, a short story, an article in newspaper, or a biography. However, each student receives a topic on which to become an expert.

2. Expert group discussion, meaning that students with the same topics meet in expert groups to discuss them 
3. Home group reporting, meaning that after they have discussed the material given in expert group discussion, they return to their home teams to report what they have learned to their teammates.

4. Testing. In doing the assessment, the students take individual performance, which result in team scores.

5. Group recognition. This kind of team recognition is the same.

Both of these techniques mainly emphasize on instruction of how to teach the real speaking competency. Teacher's help has a primary role to arise students' willingness to speak. The teacher organizes the whole speaking class for the entire class and gives the students guided practice, direct modeling, and unequivocal instruction, and then transferred the leading role to the students, acting as a guide and assistant giving the students opportunity to participate in the speaking processes. The students construct meaning through interacting in groups interactively. Meaning construction from the teacher is strongly omitted.

\section{STAD}

STAD (Student Teams-Achievement Divisions) is described as an effective cooperative learning technique, was originally introduced by Slavin in 1994. STAD comprises common set of teaching, cooperative study in mixed-ability teams, and quizzes, with recognition or other rewards provided to teams whose members excel.

STAD includes a regular cycle of instructional activities as follows:

1. Class-presentation. In teaching, teacher first explains the material through oral presentation

2. Team study. Here, students are divided into groups and work on worksheets in their teams to master the material.

3. Test. Then, students will have to take individual quizzes or other assessment (such as essays or performances)

4. Team recognition. If the team scores achieves high-scoring teams after being computed on the basis of team members' scores, they will get certificates, a class newsletter, or a bulletin board recognizes high-scoring teams.

\section{Self-Confidence}

Self-confidence, which is one of learners' affective considerations, involves judgments and evaluation about one's own value and worth. Self-confidence can be negatively influenced learners when they think of one's self as deficient and limited in the target language. On the other hand, high selfconfidence can be positively correlated to oral performance (Heyde in Park \& Lee, 2006).

It is very crucial to know and comprehend of learners' self - confidence. Teachers can help and judge students through the undersatnding of learners' self-confidence, like how to treat learners with low self-confidence, how to develop them, or else. One of the ways to represent self-confidence is the "I can do it!" principle, or the self-confidence principle. At the soul of all learning is one's belief in his or her own ability to accomplish a task. Simply put, based on Brown (2000), self-confidence is the learners' belief that they undeniably are fully capable of achieving assigned tasks at least partially a factor in their eventual success in accomplishing the task. He also lists the application of self-confidence in instruction using these following steps:

(1) First, ample verbal and nonverbal assurances are given to students. It would help a student to hear a teacher to affirm a belief in the students' ability. To tackle the problem at hand, the learner would direct at avoidance or at erecting emotional walls of defense,

(2) Second, series of techniques from easier to more difficult are prepared. Teachers are called on to sustain self-confidence where it already exists and to build it up where it does not. Teachers' main activities in the classroom would therefore start with simpler techniques and simpler concepts to the more complex ones. Students then can establish a sense of triumph that catapults them to the next, more difficult, step.

\section{METHODS}

This experimental study was restricted on investigating the effect of Jigsaw II and STAD as well as self-confidence on students' speaking competency in learning English. It was also limited on investigating the interactional effect between teaching techniques (Jigsaw II and STAD) and also selfconfidence upon students' English speaking competency. It was followed by checking out whether this 
interactional effect affects students' English speaking competency. The research was conducted in FKIP University of Mahasaraswati Denpasar, predominantly at the second semester students in the academic year 2012/2013. The research sample was grouped into the students with high self-confidence and the students with low self-confidence who were taught by using Jigsaw II which was compared to those taught by STAD.

This study was conducted at the second semester of FKIP University of Mahasaraswati Denpasar. As the sample, 68 students were selected. The research made use a Posttest Only Control-Group Design using a $2 \times 2$ factorial arrangement. For the data collection, speaking competency test in the form of performance test and self-confidence questionnaire were administered. The speaking performance test was by means of 5 criterions, which were adapted from Council of Europe and National Board of Education, with three major topics; health, education, and environment. The questionnaire was made into likert scale with 5 options. The self-confidence questionnaire consisted of 17 items were administered to the research sample. Meanwhile, for the treatment instruments, lesson plans and teaching handout were used. The data instruments were tried out first and it was found that the instruments were reliable and valid. The collected data were analyzed using Two-Way Anova and Tukey test assisted by SPSS 16.0.

\section{FINDINGS AND DISCUSSION \\ Data Description}

Data descriptions of the central tendency (median, mean, and mode) and the spread of dispersion (standard deviation, variance, range, minimum, and maximum) of the eight groups of data (A1, A2, B1, B2, A1B1, A2B1, A1B2, A2B2) were presented in table 01 below:

Table 1. The Summary of the Calculation of Central Tendency and Dispersion

\begin{tabular}{|l|r|r|r|r|r|r|r|r|}
\multicolumn{1}{c|}{ Statistics } & A1 & \multicolumn{1}{c|}{ A2 } & \multicolumn{1}{|c|}{ B1 } & \multicolumn{1}{c|}{ B2 } & A1B1 & A2B1 & A1B2 & A2B2 \\
\hline Mean & 81.18 & 72.94 & 81.18 & 66.76 & 89.18 & 71.29 & 73.18 & 74.59 \\
\hline Median & 82.00 & 72.00 & 80.00 & 70.00 & 88.00 & 72.00 & 76.00 & 76.00 \\
\hline Mode & 88 & 72 & 80 & 70 & 88 & 72 & 76 & 76 \\
\hline Std. Deviation & 9.213 & 2.964 & 3.705 & 5.205 & 3.678 & 2.544 & 5.053 & 2.425 \\
\hline Variance & 84.87 & 8.784 & 13.72 & 27.09 & 13.52 & 6.47 & 25.52 & 5.88 \\
\hline Range & 32 & 12 & 10 & 20 & 12 & 8 & 16 & 8 \\
\hline Minimum & 64 & 68 & 75 & 55 & 84 & 68 & 64 & 72 \\
\hline Maximum & 96 & 80 & 85 & 75 & 96 & 76 & 80 & 80
\end{tabular}

\section{Prerequisite Tests for the Hypotheses Testing}

Before analyzing the collected data using Two Way Anova, two major assumptions must be revealed, namely normality testing and homogeneity testing. Normality testing was administered through Kolmogorov-Smirnov formula while homogeneity testing was done through Levene's test of Equality of Error variance.

Based on the data calculated by SPSS 16.0, it was found that the distribution of all the groups of data was normal. It was proven by the value of Kolmogorov-Smirnov in which Asymp. Sig (2-tailed) > 0.05 for all groups of data. Meanwhile, based on the Levene's test of Equality of Error Variance, it could be concluded that the significant values based on mean were all above 0.05 . Therefore, it was ensured that the speaking competency data was homogenous.

\section{Hypothesis Testing}

The hypothesis testing was afterward done which resulted on rejecting the first three null hypotheses or accepting the following alternative hypotheses, and accepting the fourth null hypothesis or rejecting the alternative hypothesis.

\section{Hypothesis 1}

Based on the first hypothesis testing, it was found that the main effect of teaching techniques significantly affect the students' speaking competency. It was confirmed by the result of two-way Anova that the value of $F_{A}$ is 89.703 and the value of $F_{c v}$ is 3.99 in which $F_{o b}>F_{c v}$, so that Ho was rejected and $H_{1}$ 
was accepted. Further, it was calculated that the mean score of the students taught by Jigsaw II ( $\left.\bar{X}_{A 1}\right)$ was 81.18 while the mean score of the students who were taught by STAD $\left(\bar{X}_{A 2}\right)$ was 72.94 . These findings indicated that the participants in the Jigsaw II group achieved better in speaking competency compared to STAD. This was in line with the research conducted by Wang (2009), Jigsaw II did not only promote the achievement of integrated skills, in this case there were three skills involved - reading, listening and speaking - in process but also encouraged the affective domain of the students because the procedure of Jigsaw II obliged students to get actively involved.

In this research, the subjects under study of Jigsaw II group were trained to activate the five syntax of teaching during the instruction in getting the knowledge. The students were also led to do independent reading and active listening to ensure information passed through speaking. They learned how to speak up ideas, thoughts and opinions, as well as how to respond to it in a discussion, and then delivered what they had learned in the form of presentation to the others. As in the syntax of teaching, which was Expert Group Discussion, required the students to encourage themselves as an important member of a cooperative study group to study and to comprehend the information through discussion because they were obliged to transfer the information to their home respective groups. As known from the cooperative learning essential was the success of one's group depended on group member individual contribution. This was in light with one of the cooperative learning elements, which was for example individual accountability. This teaching technique forcefully entailed the students to stimulate their own responsibility to other study group members in Home Group Reporting. Whereas, in groups taught by STAD, the syntax of teaching used, which was for example Team Study, required the subjects under study to encourage each other only within groups.

\section{Hypothesis 2}

In investigating the interactional effect between the implementation of teaching techniques in relation to self-confidence toward the students' speaking competency, the second hypothesis testing was done. The findings showed that the null hypothesis was rejected and the alternative hypothesis was accepted. It means that there is a significant interactional effect between teaching techniques and self-confidence on the students' speaking competency. It was proven by the estimation results administered by two-way Anova that the value of $\mathrm{F}_{\mathrm{AB}}$ is 123.094 which is higher that the value of $\mathrm{F}_{\mathrm{cv}}$ that is 3.99. It concluded that not only did teaching tecniques influence the students' speaking competency, but also the self-confidence did.

As cited from a study conducted by Tong (2004) that resulted on the solid realation between a positive self-confidence with students' performance on learning task. The more positive the students saw themmselves in learning, the better performances they had. It could be assumed after the result of the second hypothesis testing that teaching techniques and the level of self-confidence could affect students' speaking competency.

\section{Hypothesis 3}

According to the result of the third hypothesis testing using Tukey test, it was found that the difference between those two groups could be seen on the Tukey test of 23.66 which was higher than the $\mathrm{Q}_{\mathrm{cv}}$ of 2.96. It meant that there was a significant difference between the high self-confidence students who were taught by Jigsaw II and those who were taught by STAD. The mean score of the students' speaking competency taught by Jigsaw II $\left(\bar{X}_{A 1 B 1}=89.18\right)$ was higher than the mean score of the students' speaking competency taught by STAD $\quad\left(\bar{X}_{A 2 B 1}=71.29\right)$ which showed that those who were taught by Jigsaw II achieved better than those who were taught by STAD.

In contrary, the students who had high self-confidence taught by STAD could not achieve as high as Jigsaw II group of students with high self-confidence. It was due to the students' self confidence of which the students felt more contagious than the low self-confidence students so that they tended not to be able to face argumentative situations in pairs discussion wherein they were supposed to respect and respond other's opinions. On the other side, because the high self-confidence students felt confident to face challenges ahead, when being taught by Jigsaw II, they delivered the materials to the other members of the group confidently and accurately. They felt confidence on their capability whether they were proficient or less proficient. They saw learning as an effort that they must encounter. Therefore, Jigsaw II 
which promoted and respected the attempt of each member was suitable to teach high self-confidence students. Likewise, a study conducted by Prom-D (2012) which found that the Jigsaw II increased the students' achievement significantly at the level 0.05 . It was also in light with the study conducted by Sahin (2010), which resulted that Jigsaw II also encouraged the increase of students' self confidence besides an improvement of students' achievement.

\section{Hypothesis 4}

As resulted from the fourth hypothesis testing, for the students who had low self-confidence, there is no significant difference between those who were taught by Jigsaw II and those who were taught by STAD. The mean score of the students' speaking competency taught by Jigsaw II $\left(\bar{X}_{A 1 B 2}=73.18\right)$, whereas the mean score of the students' speaking competency taught by STAD $\left(\bar{X}_{A 2 B 2}=74.59\right)$ which indicated that there was a slight difference in their speaking competency. This can also be seen on the Tukey test of 1.88 which is lower than the $\mathrm{Q}_{\mathrm{cv}}$ of 2.96. It was mostly due to the teaching techniques used in those two groups.

As known that Jigsaw II and STAD belonged to cooperatve learning approach, in which they generally had the similar elements of cooperative learning. Therefore, the same phenomenon went to either the Jigsaw II or STAD group. In STAD, the low self-confidence students were encouraged to tag along into discussion with their pairs. They could ask questions if they did not understand the materials before asking the teacher. They were benefited from the pairs as pairs must have helped the other members of group to get the materials in order to pass the testing session by doing speaking performance test in front of the class in the form of presentation by picking one question using lottery. If one member failed then all members did not get the group recognition. Likewise, in Jigsaw II, the low self-confidence students were challenged to take responsibility of the success of the group. It seemed that the concept of sink and swim together occured in these both teaching techniques groups. It can be concluded that the low self-confidence students can be taught using Jigsaw II and STAD.

Likewise, a study from Felder and Brent (2007) that described various cooperative learning techniques which have been confirmed effective in different classroom settings. It was also stated that there were several reasons why cooperative learning was able to give positive effect towards students' achievement. The teaching techniques of cooperative learning suggested to the weak students, who eventually got stuck when studying alone, to keep going by working cooperatively with strong students wherein the strong students were motivated to work in an appropriate manner to take charge of explaining and clarifying the materials to the weaker students so they could pass the learning together.

\section{CONCLUSION AND SUGGESTION Conclusion}

Based on the findings and discussion above, it can be seen that there was a significant difference in speaking competency between the students who are taught by Jigsaw II and those by STAD. The students in the Jigsaw II group achieved higher speaking competency than those in the STAD group. Moreover, there was an interactional effect between teaching techniques and self-confidence on students' speaking competency. Furthermore, there was a significant difference in speaking competency between the students with high self-confidence who are taught by Jigsaw II and those by STAD. The students with high self-confidence who gained higher speaking competency were best treated by Jigsaw II. In addition, there was no significant difference in speaking competency between the students with low selfconfidence who are taught by Jigsaw II and those by STAD. The students with low self-confidence were best treated using either Jigsaw II or STAD.

\section{Suggestion}

This study was done to compare the effect of Jigsaw II and STAD as well as self-confidence on students' speaking competency. There are some suggestions which can be given for the readers as following: (1) It is recommended for the EFL educators to implement appropriate teaching techniques to emphasize on constructivist concept of speaking; (2) It is recommended for EFL educators of the second semester students of FKIP University of Mahasaraswati Denpasar to employ Jigsaw II as an alternative teaching technique in English speaking classroom settings.; (3) It is suggested for other researchers to conduct the same study with different participants, such as students from high schools, gifted students, 
disabled students, etc. It would be remarkable to find out whether Jigsaw II or STAD which give stronger effect toward these students and how self-confidence levels work on them; (4) This research compared the effect of Jigsaw II and STAD upon students' English speaking competency. Jigsaw II or STAD may be compared to other teaching techniques to deliberate which one is beneficial for the increased achievement on speaking competency.

\section{REFERENCES}

Brown, D. 2000. Principles of Language Learning and Teaching. New York: Longman.

Brown, D. 2000. Teaching by Principles: An Interactive Approach to Language Pedagogy $\left(2^{\text {nd }}\right.$ Ed). New York: Longman.

Brown, D. 2003. Language Assessment Principles and Classroom Practices. New York: Longman.

Celce-Murcia, M. 1991. Teaching English as a Second or Foreign Language ( $2^{\text {nd }}$ Ed). New York: Heinle \& Heinle Publishers.

Cohen, E., Brody, C. and Sapon-Shevin, M. 2004. Teaching Cooperative Learning: The Challenge for Teacher Education. New York: State University of New York Press.

Felder, R. and Brent, R. 2001. "Effective Strategies for Cooperative Learning", J Cooperation \& Collaboration in College Teaching, No. 2, Vol. 10, Hal. 69.

Felder, R. and Brent, R. 2007. Cooperative Learning. ACS Symposium Active Learning: Models from the Analytical Sciences. Washington, DC.

Harmer, J. 1998. How to Teach English, An Introduction to The Practice of English Language Teaching. New York: Longman.

Harmer, J. 2007. The Practice of Language Teaching $\left(4^{\text {th }} E d\right)$. New York: Longman.

Herrell, A. and Jordan, M. 2004. Fifty Strategies for Teaching English Language Learners $\left(2^{\text {nd }}\right.$ Ed). New Jersey: Pearson.

Hiçyilmaz, A. 2005. “A Review of Cooperative Learning”. Turkish School of Linguistics.

Johnson, R. T. and Johnson, D. W. 2009. "An Educational Psychology Success Story: Socal Interdependence Theory and Cooperative Learning", American Educational Research Association, No. 5, Vol. 38, Hal. 365.

Johnson, D. W.; Johnson, R. T.; Stanne, M. E. 2000. Cooperative Learning Methods: A meta-analysis. University of Minnesota, Minneapolis: Cooperative Learning Center; http://www.cooperation.org/pages/cl-methods.html (accessed $5^{\text {th }}, 2012$ )

Khan, G., N. 2011. "Effect on Students' Team Achievement Division (STAD) on Academic Achievement of Students", Asian Social Science, No. 12, Vol. 7. Hal. 211.

Luoma, S. 2004. Assessing Speaking. Cambridge: Cambridge University Press.

Marhaeni, A., A., I., N. 2010. Asesmen Bahasa yang Bermakna. Orasi Pengenalan Jabatan Guru Besar Tetap dalam Bidang Ilmu Pendidikan Bahasa Inggris pada Fakultas Bahasa dan Seni Universitas Pendidikan Ganesa. Singaraja: Universitas Pendidikan Ganesha. 
Maharani, A., A., P. 2012. The Effect of Reciprocal Teaching and Self-Concept upon the Reading Comprehension of the Tenth Grade Students of SMA Negeri 1 Gianyar. (Thesis). Singaraja: Universitas Pendidikan Ganesha.

Molberg, H., K., K. 2010. The Consequence of Motivation and Linguistic Self-Confidence in Relation to Pupils' Oral Interaction. (Thesis). Tromso: Universitetet i Tromso.

Park, H. and Lee, A. 2006. "L2 Learners' Anxiety, Self-Confidence and Oral Performance", Modern Language Journal, No. 1, Vol. 82, Hal. 197.

Prom-D, D. 2012. The Effect of Jigsaw II Technique on Reading Comprehension of Mattayom Suksa 1 Students. (Thesis). Bangkok: Srinakharinwirot University.

Richards, J. 2008. Teaching Listening and Speaking: From Theory to Practice. Cambridge: Cambridge University Press.

Richards, J. and Rodgers, T. 2001. Approaches and Methods in Language Teaching. Cambridge: Cambridge University Press.

Rubio, F. 2007. Self-Esteem and Foreign Language Learning. Newcastle: Cambridge Scholars Publishing.

Sahin, A. 2010. "Effects of Jigsaw II Technique on Academic Achievement and Attitudes to Written Expression Course", Educational Research and Review, No. 12, Vol 5, Hal. 777.

Slavin, R. 2009. Educational Psychology Theory and Practice. New Jersey: Pearson.

Tong, J. 2004. Little Voice: Students' Confidence and Their Responses in English Lessons. The Journal of Asia TEFL. No. 1, Vol. 1, Hal. 197.

Wang, T., P. 2007. "The Comparison of the Difficulties between Cooperative Learning and Traditional Teaching Methods in College English Teachers", The Journal of Human Resource and Adult Learning, No. 2, Vol. 3, Hal. 23.

Wang, T., P. 2009. “Applying Slavin's Cooperative Learning Techniques to a College EFL Conversation Class", The Journal of Human Resources and Adult Learning, No. 1, Vol. 5, Hal. 112. 